\title{
ARTICLE
}

\section{Social and Environmental Justice for Communities of the Mekong River}

\author{
Dani J. Barrington, ${ }^{*}$ Stephen Dobbs, ${ }^{\dagger}$ and Daniel I. Loden ${ }^{\ddagger}$ \\ * The University of Western Australia, dani.barrington@gmail.com \\ † The University of Western Australia, stephen.dobbs@uwa.edu.au \\ ‡ Engineers Without Borders Australia, d.loden@ewb.org.au
}

\begin{abstract}
During the mid-twentieth century the construction of hydroelectric dams in developing countries became a contentious issue in economic and political arenas. Governments and pro-damming parties, particularly those with a direct commercial interest, often consider the dams to be necessary for economic growth, as well as being in the national interest. Others directly impacted by the altered hydrology and ecology, as well as experts concerned with environmental and demographic impacts, are less sure about the benefits of hydro-electric dams. Concerns about the environmental and human impacts of dams are heightened on a waterway such as the Mekong River, which flows through six sovereign states. When the impacts are to be felt across entire regions, ensuring just outcomes for all the stakeholders is crucial to long-term regional political stability and economic wellbeing. Engineers are pivotal in the design and construction of dams, and engineering teams also play an increasingly important role in assisting communities impacted by the altered hydrology. This article focuses on the community and environmental implications of engineering decisions on the Mekong River, and suggests ways in which engineers involved in dam design and construction can play a role in ensuring that socially and environmentally just outcomes are achieved.
\end{abstract}

KEYWORDS: dams, Mekong, water rights, Engineers Without Borders

\section{INTRODUCTION}

The Mekong River is the twelfth longest waterway in the world, stretching to well over 4000 kilometres in length (Jacobs, 2002). It begins its course in the high reaches of eastern Tibet before winding its way through the modern Southeast Asian states of Myanmar, Laos, Thailand, Cambodia and Vietnam. For a little less than half its total length, the Mekong runs through China's southern province of Yunnan and is known as the Lancang River (Figure 1).

The waters of the Mekong sustain a population of more than 70 million people (which is expected to keep growing) who are heavily dependent on the river for their livelihoods in fishing and agriculture (Jacobs, 2002). The river is the basin's main source of protein and sustenance through these occupations. Historically, it has sustained people and cultures of great diversity, as well as having provided the hydrological basis for some of the world's most impressive civilizational undertakings, such as the great Cambodian empire founded at Angkor near modern day Siem Reap. The Mekong and its environs are undergoing rapid change and transformation, as the modern nation states through which it courses look to it as a national resource to be exploited. The Mekong Basin is one of Southeast Asia's most contested political, social and environmental arenas. Whist there are many issues relating to various development projects that are cause for concern, the damming of the river to harness its potential as a source of hydroelectricity looms as a major threat to the riparian communities of the Mekong. Communities who are often already "impoverished" are 
further threatened by decisions about "large scale transformations designed and decided in other spheres, often without their knowledge" (Molle, Foran, \& Kakonen, 2010, p. 2). Broadly speaking, the building of dams threatens domestic stability through displacement of people and loss of livelihoods, and threatens regional political stability as development projects in one national jurisdiction impact on neighbouring national jurisdictions.

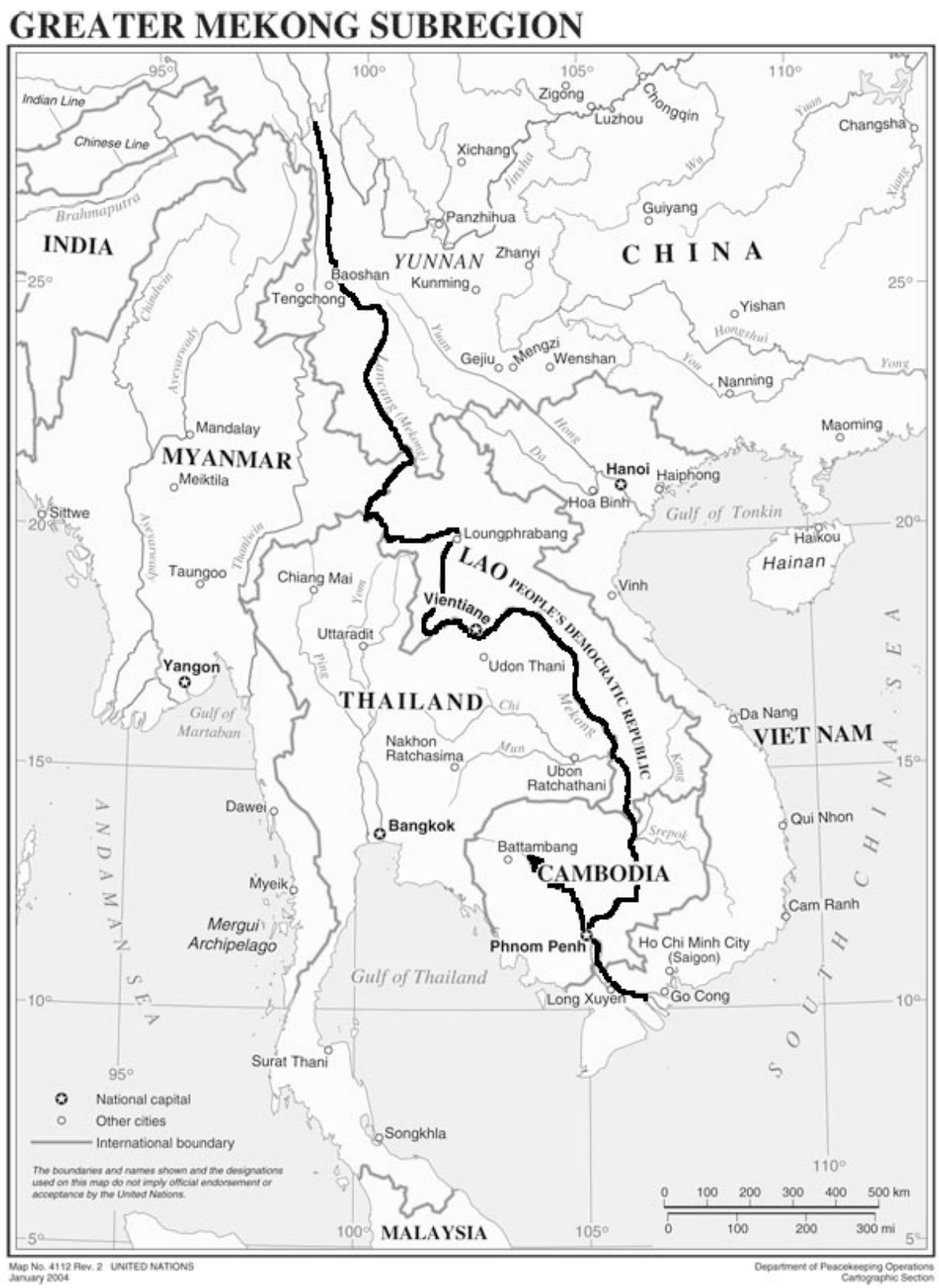

Figure 1: Map of South East Asia showing the route of the Mekong River (United Nations Department of Peacekeeping Operations Cartographic Section, 2004).

The purpose of this paper is to explain the role that engineers can play in supporting social and environmental justice for the communities of the Mekong River system. The paper starts by discussing a theoretical framework the authors believe can be utilised for understanding what they mean by social and environmental justice in the context of the culturally, politically and ecologically sensitive Mekong Basin. This is followed by a short history of the Mekong River, highlighting its life- 
and culture-supporting roles within the societies and communities of the region. Due to the significance of the river to riparian communities, the paper explores the impacts of dams on natural resource management and the mechanisms which exist to protect the rights of traditionally underrepresented groups. The impact of existing dams on the Mekong River is outlined focusing on the social justice impacts of their construction. The role of engineers in conceptualisation, design and delivery of large-scale dam projects is then explored to highlight the role that these individuals and the engineering profession can play in helping to ensure social justice for the developing communities of the Mekong River system, as well as the tools available to support this work. The paper concludes by outlining the role that engineers and organisations need to play in the future to ensure social and environmental justice for communities along the Mekong River.

This paper highlights the complexity of issues involved with major engineering projects such as dam building in a region of such social, cultural, economic and political diversity. In contextualising the impacts of dam building along the Mekong within a discourse of social and environmental justice, the authors are aware of the multiple meanings and vagaries such terms conjure up. Both are, as Nussbaum stresses for social justice, "profoundly normative" concepts (Nussbaum, 2003), heavily dependent on the context and background of the user. The starting position of the authors is that "social and environmental justice" needs to be viewed as intertwined with other elements of basic human rights as set out in the Universal Declaration of Human Rights (United Nations, 1948). While there are staunch debates about whether or not the framework for international human rights is too closely aligned with western liberalism and its focus on the rights of the individual over the group, a concern that has been taken up by academics and other critics, particularly from the Asian region, the authors feel a rights-based approach is appropriate for establishing a framework for assessing the impacts of large hydraulic projects and the role of engineers in the Mekong region. Whilst recognising a degree of genuine concern by some observers in the critique of human rights discourse, most states have "explicitly endorsed" the rights encapsulated by the Universal Declaration whether or not in practice they adhere to them (Donnelly, 2006). Arguments against a rights-based approach to issues of national interest in the Asian region by states are often what Donnelly has called "weak based relativism" which attempts to provide an "antiquarian" justification for modern abuses (Donnelly, 2006).

\section{Environmental and Social Justice and the Rights-Based Approach}

Environmental and social rights or justice, in the view of the authors, can clearly be framed within the broader context of human rights discourse, as Adeola (2000, p. 689) notes, "because human rights involve the assurance of people's means of livelihood, any threats to the environmental bases of livelihood could be considered a violation of basic human rights". It also seems to the authors that the links between social and environmental justice and human rights are often specific and immediate as in many developing regions of the world "environmental injustice and human rights violations are inextricably interwoven" as states appropriate the resources of minority groups, ethno classes and people of lower socio-economic status in the name of economic and national development (Adeola, 2000, p. 687). In almost all the hydraulic projects in the Mekong Basin, it is more marginalised groups who will feel the immediate social, cultural and economic impacts. Within the context of Southeast Asia, it is also worth noting that despite a long period of rapid economic growth and industrialisation in almost all countries along the Mekong, a majority of people "live in rural areas and depend in greater or lesser degree for the livelihood on their immediate physical environment ... any encroachment on forest, land, and water resources on which people depend is also a claim on their sustenance, hence the inseparability of social impact and environmental degradation" (Hirsch, 1998, p. 56). 
China, as a staunch opponent of any rights-based criticisms of its policies and a major player in terms of the future of the Mekong River, is increasingly being forced to deal with the negative environmental consequences of its rapid development (see for example Economy, 2005; Smil, 2004). The authors believe these consequences are forcing China to acknowledge the rights of minority and community groups affected by development. Recent state rhetoric suggests that within official communist party circles there is a growing recognition of the need for new approaches to economic development which factor in environmental and social/cultural elements. McLaren (2011) suggests that Hu Jintao's call in 2007 for an "ecological civilization" followed up by discussion of "scientific development" rather than "economic construction" was tied to the growing "plurality discourses" on the environment in China, and official recognition that development at any cost is unsustainable. McLaren also notes that within the context of China there is seen to be a close relationship between culture and the "eco-site" that nurtured it, thus a growing concern about the "sustainability of China's unique 'ecological civilization"' (2011, p. 431) as the environment is degraded. Not inconsequentially for this paper, McLaren highlights the importance of the Southeast Asian massif (which includes much of the Mekong Basin area) with regard to these dual concerns with "bio and cultural diversity" (2011). Hence, the authors hold the view that whilst refraining from discussing these issues in a discourse of rights, even the Chinese state is acknowledging the rights of ethnic and other communities to greater participation and determination of their futures.

Engineers are not neutral bystanders in these political, economic and environmental struggles but rather-such as with damming projects along the Mekong-active players. Whether they recognise it or not, the decisions they make with respect to projects they work on means they are political players and complicit in outcomes that lead to the curtailment or infringement of affected people's rights. This paper accepts the proposition put forward by Riley that the Marxian concept of praxis "is at the heart of what engineering and social justice must be about" (Riley, 2008, p. 108). To achieve what Rawls has termed "justice as fairness" (Rawls \& Kelly, 2001), in the context of Mekong projects praxis means that local communities and engineers should be fully and meaningfully involved in the processes that lead to decisions being made on whether or not particular developments proceed. Similarly, mechanisms need to be in place to ensure that parties adversely affected by projects such as dams are appropriately and adequately compensated for social, cultural and economic dislocation where this cannot be avoided. It is the view of this paper that engineers and companies involved in major projects such as dam construction (often these are large foreign commercial interests) should be active in ensuring that they not only meet high technical standards but also high standards in public consultation and social/environmental impact assessment. Individually, the authors would argue, praxis can enable engineers to play a crucial role in ensuring just social and environmental outcomes-whether through application of their technical skills or through withdrawal of these same skills and expertise. The lessons that might be learned from the hydroelectric development schemes in this politically, culturally, demographically and economically complex region have potentially universal applicability.

\section{Historical SETtING}

The rich and diverse waters of the Mekong have historically made possible the establishment of communities and polities of immense size and complexity. One of the earliest such kingdoms, Funan, located on the eastern side of the Gulf of Thailand, was chronicled by Chinese emissaries. According to the Chinese accounts, Funan was a major port where silk and various sorts of highly valued resins, aromatic woods and other produce of the Southeast Asian region found their way into the lucrative east/west trade system (Shaffer, 1996). The waters of the Mekong and fertile delta supported the development and population of this kingdom (Vickery, 1998) as well as a large number of traders and visitors who would sometimes have to spend months there waiting on the 
change of monsoon to begin their outward voyages (Hall, 1992). Whilst knowledge of this early Mekong-based kingdom is scant, another great Cambodian kingdom of the Mekong, Angkor, has numerous monuments to its greatness. The Angkorian period from the ninth to fifteenth century witnessed the flourishing of an empire that extended its reach into the modern states of Vietnam, Laos and Thailand.

Perhaps most remarkable was the extent of the population that lived at Angkor. At its centre it supported in excess of one million people (Osborne, 2000a). It is in this respect that the Mekong was so important to this great civilizational achievement. Water was crucial to the Angkorian kingdom, as it provided the ability to farm rice and harvest protein rich fish. Angkor was located near the northeastern shore of Southeast Asia's largest fresh water lake, Tonle Sap, and it was the Mekong that sustained the great lake then as it does now. During the monsoon season, the Mekong forces water to rush up its tributary, the Tonle Sap River, into the lake, and the water retreats as rainfall decreases (Keay, 2005). The great Tonle Sap only exists as a consequence of these annual reverse flows, and its role as the major source of protein in Cambodia hinges critically on this natural annual cycle. The quantity of fish supported in this ecosystem makes the lake one of the world's biggest freshwater fisheries (Keay, 2005), a role that marked its importance to both Angkor and the modern Cambodian state. Chou Ta-kuan, a Chinese envoy, who visited Angkor for a period of more than a year, arriving in April 1296, has provided the only contemporary eyewitness account of the role of water flows into and out of Tonle Sap in Angkorian agriculture. According to his account, three rice crops were grown each year by following a natural irrigation pattern based on the rise and fall of the great lake as governed by the flow of the Mekong River (Osborne, 2000a). As the lake rose and fell by as much as twelve metres, Chou's account describes Angkoreans moving with the water to plant their rice crops (Osborne, 2000a). Historically this Mekong based ecosystem has sustained a vast wealth of ecological diversity and great cultural achievements, and its ability to nurture this diversity has outlasted these earlier human political, social and economic constructions. The system now faces new and arguably much greater forces of human intervention where for the first time the entire ecology of the Mekong, its environs and those people whose lives depend on it are at risk.

\section{The Mekong Dams And Resource Management}

The building of large dams, as noted by Hirsch, has resulted in "environmental degradation and marginalization of affected people as a general, if not universal, experience" $(1998$, p. 56). Dam building along the Mekong has occurred since the 1980s, with China leading the way. The Mekong begins its long meander to the coast from the Tibetan Plateau as the Lancang River. Currently China has four hydroelectric dams operating along this reach of the river. Three of these dams, the Jinghong, Manwan and Dachaoshan, have a generating capacity of 4,350 MW each. The most recently operational dam Xiaoman is the second largest hydroelectric dam in China with a capacity of 4,200 MW (Osborne, 2009). An even larger capacity dam, the Nuozhado (5,850 MW), is currently being constructed (Chinese National Committee on Large Dams, 2011). As China continues to push ahead with its program of economic transformation, a further three dams are proposed by 2030 (Osborne, 2011), the Gongguoqiao, Ganlanba and Mengsong dams, which when complete will bring the total number of dams along the Lancang to eight (Figure 2). 


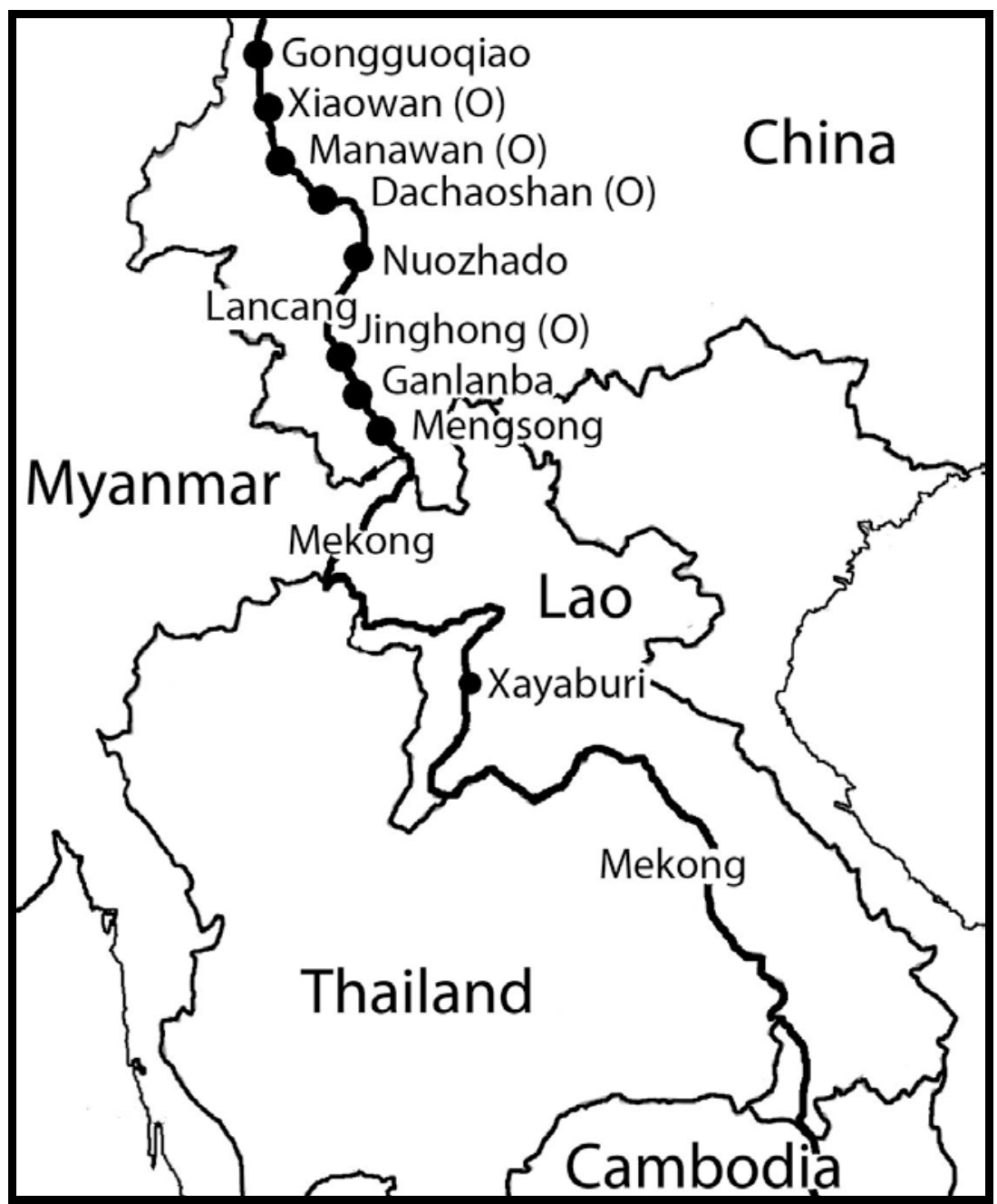

Figure 2: Map showing approximate location of dams discussed in paper. (0) Indicates dams already operational.

Many analysts have growing concerns about the impact of these dams on communities and states along the water course, with long time Mekong watcher Milton Osborne noting "it may be some years before the full effects of China's dams are apparent, there is no doubt many will be negative" (Osborne, 2011). Concerns have been exacerbated by plans by some Mekong riparian states to build even more dams along the main body of the river, the impacts of which Osborne notes will be almost "immediate and dangerous" (Osborne, 2011). Whilst many such plans have been discussed and examined over the past half century, there has been little action until recently, with the Laos government (as of 2011) proceeding with plans to build a 1,260 MW hydroelectric dam at Xayaburi despite the protestations of Cambodia and Vietnam (Vietnam Business and Economy News, 2011). As debate and concern continues over the impact of damming along various tributaries of the Mekong, the Xayaburi dam, if it is built, will be the first outside of China to interrupt the flow of the Mekong. With various proposals for up to ten more dams along the Mekong (Bangkok Post, 2011b), there has to be concern that if Laos pushes ahead with the Xayaburi project despite the concerns of its neighbours, more of these other "proposed" projects will become reality.

Issues relating to the Mekong as a resource and region of development are currently under the perusal of two regional bodies, the Mekong Committee/Mekong River Commission (MRC) (1957/1995) (Mekong River Commission, 2010) and the Greater Mekong Sub-Region (GMSR) 
(1992) (Asian Development Bank, 2011). This is a very important issue because of the number of riparian states involved and the potential for conflict. Both of these organisations interest themselves in the development and sustainability of the Mekong environment and environs. The idea of development in the Mekong region, as Osborne notes, started out very much as a product of Cold War politics supported by the United States, which has seen the river basin's development as closely linked to their war against communism in Southeast Asia (2000b).

These formal organisations (MRC and GMSR) seemingly have at the forefront of their deliberations concerns about the sustainability of the region and preservation or improvement of people's standards of living. However, they can only act in an advisory capacity and have no ability to regulate, so they are not responsible for ultimate outcomes. The public faces of the MRC and GMSR promote the desirable goals of protecting diversity and the environment whilst promoting development that is sustainable and "socially just" (Mekong River Commission, 2010). Clearly, however, there is cause for serious concern when it comes to the issue of how achievable these goals are in the context of national interests being given priority. The MRC is an international, country-driven river basin organisation that provides the institutional framework to promote regional cooperation (Mekong River Commission, 2010). The commission has done excellent work in publicising the impacts of activities along the Mekong, but has had a limited impact on policy. This is attributed to a lack of political power of the organisation, and the fact that China and Myanmar, two nations that significantly impact the Mekong, are not part of the Commission. As these organisations have no political authority, they have limited ability to influence decisions being made about the river's future at the national level within particular countries. The lack of dialogue and influence of these regional bodies within the countries of Southeast Asia effectively silences the voice of Mekong communities at the discussion table.

Without effective political leadership, downstream nations will continue to feel the impacts of upstream activities. With an ever-increasing population and demand for natural resources, this has significant potential to lead to conflict over water access (Cambodia Engineers Without Borders Returned Volunteer, interviewed 10Nov2010; Cambodia Engineers Without Borders Community Partner, interviewed 2Nov2010). Nothing highlights better the weakness of these bodies than Laos proceeding with the Xayaburi dam against the advice of the MRC (Bangkok Post, 2011a). Likewise, the vested interests of different states seem to dictate how they respond. In the case of Xayaburi, Cambodia and Vietnam have raised their concerns whilst Thailand, set to be a major beneficiary via the purchase of the generated electricity, officially remains largely silent about the issue.

It would seem logical that nations would want to recognise that they have a shared benefit from, and shared responsibility to protect, the Mekong River system. Yet whilst countries are not required to identify the social, economic and environmental consequences of dam building both within and outside their national borders, economic interests of individual states trump all other concerns. The risks involved in states taking a "go it alone" approach are not simply about possible national conflicts. There are very clear threats to entire ecosystems outside the borders of the go-italone state which could see impacted communities displaced and an enormous humanitarian crisis develop.

\section{IMPACTS OF DAMMING THE MEKONG}

It is in the assessment of potential benefits and costs that effective praxis is crucial for all parties involved, including those individual engineers involved in design and implementation. Meaningful praxis in this context involves engagement with all stakeholders. Most importantly, local communities, where impacts of dams will be most immediately felt, need to be active participants in 
decision making to ensure that their rights to just social and environmental outcomes are met. It is without question, with regard to damming in the Mekong Basin, that the process of decision making continues to be a "top-down" one with decision makers far removed from the lives of affected peoples (Mitchell, 1998). The following discussion suggests that support for dam construction in the national interest is at the very least highly problematic when potential benefits and costs are compared.

\section{Benefits of Dam Construction}

All countries along the Mekong River system believe that dams are necessary to meet the growing domestic demand for energy, and to provide income. Hydroelectricity dams generate income from the sale of electricity to neighbouring communities and countries and provide benefits to both recipients and producers. The Xayaburi dam, for example, will supply 1,285 MW (close to its entire capacity) of electricity to the Electricity Generating Authority of Thailand (Bangkok Post, 2011a). Stimulation of the local economy can be considered socially just on a national scale, particularly in low-income countries, where this new market may help to increase the per capita GDP above poverty levels (Bakker, 1999). Dams allow for greater control of river flow, which during the dry season can assist in increasing water availability (Lu \& Siew, 2006), and decrease saline intrusion (Kummu \& Varis, 2007), resulting in better irrigation of crops. Dams also allow for greater navigation of the river from the addition of locks and the slowing of river flow (Kummu \& Varis, 2007). The feedback from some Vietnamese communities along the river has been that these developments are beneficial as they enable the provision of services to the community that would be otherwise unobtainable (Vietnam Engineers Without Borders Volunteer, interviewed 4Nov2010).

\section{Negative Consequences of Dam Construction}

Despite the potential benefits, independent studies, details of which are outlined below, have observed that there are many negative social and environmental impacts associated with hydroelectricity dams, particularly along the complex Mekong River system. These include:

- Loss of migratory fish species

- Loss of protein source and income for communities

- Loss of nutrient rich soil deposits

- Reduced hydroelectric capacity over time

- Eco-system shifts

- Salt intrusion

- Loss of fish spawning grounds

- Loss of livelihoods and homes

The following sections examine in more detail these impacts and how they are already affecting the Mekong River system. Further hydropower project developments will only exacerbate existing problems.

\section{Loss of migratory fish species}

A major detrimental effect of dams is the alteration of fish migration patterns through river systems (Dugan et al., 2010; Kang et al., 2009). These animals play a crucial role in the biodiversity of the Mekong system, as well as providing a source of food and income to communities along the river. Although it is possible for engineers to design systems such that fish can pass through hydroelectric turbines (Coutant \& Whitney, 2000; Schilt, 2007), this has not been seen on any of the existing designs and constructions along the Mekong, and is not considered to be a viable solution to the 
massive fish migration along the Mekong system (Kang et al., 2009). The loss of migratory fish presents both an environmental and social issue within the Mekong system. The biodiversity of the Mekong is second only to the Amazon, and many endangered species, such as the Mekong giant catfish and the Irrawaddy dolphin, may become extinct if they are eradicated from the river system (Baird \& Beasley, 2005; Ngamsiri et al., 2007). As Dugan et al. note, unless investment and innovative ways of dealing with these issues in the context of the Mekong are found, "current best evidence suggests significant and rapid loss of natural ecosystems and their services in the basin, leading to major social and economic impacts" (2010, p. 346).

\section{Loss of protein source to communities}

Fishing as an income source and the dependence on fish for food have long been a central part of the human/river interface along the Mekong. The loss of migratory fish species as a result of hydroelectricity dams poses a direct threat to the food and income security of Mekong River communities. It is estimated that no less than $80 \%$ of Cambodia's protein comes from the Tonle Sap basin (Live \& Learn Environmental Education, 2007), making it particularly vulnerable to any change in fish stocks. Recent years have seen a significant shift in the fish stocks in the river, with many of the larger fish disappearing from the system. This is attributed to climatic shifts and the impacts of upstream activities such as dams. A decrease in fish biomass means a dramatic decrease in food sources for communities, as well as a significant loss of income for the many families who rely on catching and selling fish as a means of employment (reviewed in Lamberts, 2006). The impacts of decreasing fish biomass have already been observed by communities along the Mekong system. To ensure the environmental and social wellbeing of animals and communities that depend upon the biomass provided by the Mekong, it is essential that dam engineers and designers determine ways of increasing fish migration through existing dams, and consider the impacts of future dams on the migration of river species.

\section{Loss of fish spawning grounds}

In Cambodia, it has been observed that the dry seasons are dryer and that there is more water during the monsoon. The changes in monsoon and dry-season water levels, as with other areas in the region, are attributed to two main factors, namely shifts in climatic patterns and the reduction in flow down the Mekong caused by upstream damming. This is beginning to cause problems between the fishing communities, who produce so much of Cambodia's protein, and the farming communities, who produce approximately ten per cent of Cambodia's rice. These communities are now competing over the same resource area. The rice farmers are clearing more forest during dry periods, as these locations are now viable for farming. But these forests are a key breeding ground for the fish that stock the river, which if removed risk decimating the future fish stocks of the lake (Cambodia Engineers Without Borders Returned Volunteer, interviewed 10Nov2010; Cambodia Engineers Without Borders Community Partner, interviewed 2Nov2010). Whilst Cambodia may be able to slightly increase their rice production, they will lose the fish protein which has come from Tonle Sap and the Mekong River.

\section{Loss of nutrient rich soil deposits}

The alteration of flow regime, resulting in sedimentation and erosion, is also important when considering both the upstream and downstream physical impacts of dams. By slowing river flow, and blocking solids transport, dams greatly decrease the sediment load able to flow through the system. This has many effects, including bed scouring, lateral expansion due to bank erosion, and a loss of nutrients to seasonally flooded plains downstream (Kummu \& Varis, 2007; Lu \& Siew, 2006; Zhai, Cui, Hu, \& Zhang). It is estimated that approximately 50 per cent of suspended sediments in the Mekong system originate in China, and this is decreasing with the construction of dams in the 
Upper Mekong (Fu \& He, 2007). With dams proposed along the lower stretches of the Mekong, this situation is set to become even more dramatic, with Vietnam estimating that the Xayaburi dam will reduce nutrient-rich alluvial deposits in the Mekong Delta from 26 million tonnes to 7 million tonnes (Vietnam Business and Economy News, 2011). This loss of soil nutrients for downstream farmers will result in reduced soil fertility, yields and incomes.

\section{Ecosystem shifts}

In a seasonally flooded ecosystem, permanent inundation behind dam walls will heavily impact the biodiversity and the ecosystem balance, with potentially unforeseen environmental and social consequences, including a shift in ecosystem function and a reduction in agriculture (discussed in Benger, 2007; Kummu \& Varis, 2007; Lu \& Siew, 2006). It has been suggested that a positive impact of damming the Mekong is that it allows the flow of water to be controlled, and hence will enable a higher than average dry season flow (Lu \& Siew, 2006), improving agricultural production downstream from dams. However, this optimistic view fails to consider the ecological adjustments that the environment will need to make to conform to this new mode of operation.

\section{Reduced hydroelectric capacity}

Deposition of sediments behind dam walls leads to accretion of sediments upstream of dams, which raises basin levels, further changing the flow pattern and efficiency of electricity generation. To maintain the dam's capacity, expensive and potentially damaging dredging activities are required (Fu, He, \& Lu, 2008). Several engineering models exist for estimating and minimising the negative impacts of dams on hydrological regimes. It is important that these models be considered in current design proposals for the Mekong, and that modelling of existing dams is used to assist engineers and designers in assessing and correcting problems associated with dam construction. This will benefit the country operating the dam as well as the downstream communities who rely on the annual nutrient flows for their harvests.

\section{Salt intrusion}

In Vietnam there is an emerging issue of salt intrusion into the lower regions of the Mekong due to a change in flow regime. Currently the last ten to 20 kilometres of the river experience salt intrusion, which is impacting farmers in the area. Traditionally these lower Mekong communities utilised irrigation canals to divert water from the Mekong to their farmland; however, with the water becoming saline, this is no longer viable. These farmers, who represent the poorest members of Vietnamese society, are being forced either to move to other areas or to suffer the reduced land productivity that is resulting. This phenomenon of salinization has been attributed by the locals to a combination of reduced rainfall and lower flows down the Mekong River (Vietnam Engineers Without Borders Volunteer, interviewed 4Nov2010). Further dams may worsen the issue of saline intrusion in Vietnam. This situation presents clear social injustices, as the poorest members of the last country on the Mekong are seeing the consequences, whilst the benefits of these projects are flowing to people thousands of kilometres upstream.

\section{Loss of livelihood and homes}

Dams have also been shown to heavily impact the communities immediately around them (reviewed in Tilt, Braun, \& He, 2009). The flooding of valleys to form dams often submerges cultural monuments, pastures and homes, resulting in displaced communities and economic restructuring. These are issues that have been well documented with large-scale dam projects such as the Three Gorges Dam (China) and the Sadar Sarovar Dam (India). In many communities, a shift away from traditional income generating activities has led to an increase in remittance work, meaning that in communities where males and females once worked alongside one another, males now work away 
from the family unit. In some areas, the price of electricity actually increases following dam construction, due to the increased cost of generation for large-scale hydroelectricity schemes compared to those traditionally used by small communities (Tilt et al., 2009). These changes to local economies and traditional livelihood patterns invariably impact those people with the least voice in planning discussions. In addition, the psycho-social effects of this economic restructuring on these communities has not been addressed well by engineers and designers (Scudder, 2005).

\section{Magnitude of the Consequences}

There is continued and growing community concern about the impacts of damming the Mekong River. Many believe that damming along with the impacts of climate change will directly and negatively affect livelihoods. Communities, for example in Cambodia, are concerned that reduced water flow will result in damage to the Tonle Sap and Mekong River ecospheres that they are so dependent upon (Cambodia Engineers Without Borders Volunteer, interviewed 5Nov2010). There is also concern that the change in flow regime, fish biomass and social impacts may lead to water conflict. This is an important factor for consideration of a river system which traverses six countries, and where the benefits of hydroelectricity are often being shared between neighbouring countries. Resource conflicts can be a cause of political and social unrest, and it is expected that conflicts over water are set to increase in coming years. Ismail Serageldin, Vice President of the World Bank in 1995, famously stated that wars of the twenty-first century "will be fought over water" (Shiva, 2002, p. 1). The most pressing of these issues identified is the loss of fish protein and salt intrusion on the lower Mekong. Protein forms an essential part of a balanced diet. If Mekong communities are forced to survive on decreasing protein in their diets, then the risk of infection and disease in an already marginal community will increase significantly. This is also true for the Vietnamese farmers who are being forced off their land. This process is concentrating the nation's productive land into a smaller area. Both these processes (decreasing protein in diets and loss of farmland) are very slow and could go unnoticed until it is too late to mitigate the consequences.

\section{Current Regional Development Approach}

Jacobs (1995) suggests that the relatively slow pace of developments along the river (until the mid1990s at least) might be seen as a positive outcome of the Mekong Committee, in that no big mistakes were made in terms of damming and other water projects. More recently though, major dams and other large projects have been constructed that fail to take into consideration the significant impacts of their construction for downstream communities. Without political authority, the Mekong Committee is unlikely to be able to force dam constructors to make these impact assessments in the future either. It would seem that the current framework for handling these developments is not satisfactory. Even with the best intentions the MRC has no control over what states might decide to do in what they see as their own best interest. Long-time Mekong researcher Milton Osborne notes that:

With China holding to a firm position that what it does within its own territorial boundaries is its own business, there seems no reason to expect that the projected dams on the Mekong will not be built. Since this is so, it does not seem alarmist to conclude that there is a very real possibility that in the relatively near future there could be major environmental problems for the countries on the lower Mekong. These will be problems that will be impossible to reverse short of demolishing the dams China has built. (Osborne, 2000b, p. 439)

China's reluctance to commit to water agreements is highlighted no better than by its voting against a 1997 United Nations convention which established a framework and "principles for the use of 
international rivers" (Wolf, 2003, p. 120). China will within the next decade be in a position to control the "flood pulse" of the Mekong, giving it considerable political leverage over other riparian states (Osborne, 2009). Equally alarming are recently revealed plans to build up to 11 dams along the main course of the Mekong below the border with China. Laos alone is considering the construction of dams at seven sites (Osborne, 2009).

Clearly development and management of the Mekong region is not something that should be simply left to relatively powerless regional groupings such as the MRC and GMSR. However wellintentioned these groups are, they are bound by the demands of their political masters. As Osborne observes, the only chance of meaningful changes in policy with respect to dams and other development projects is through influencing the states involved (Osborne, 2009).

It is essential that states explore all possible avenues to develop the Mekong region and provide better living conditions for citizens in the area. However, the rather secretive and arbitrary nature of the way in which various projects have been undertaken (with respect to dam proposals and developments along the Mekong) suggests that meaningful consultation is often lacking or ignored. International pressure is being exerted through the International Declaration of Human Rights, the Rio Declaration of Environmental and Development principles and the work of the World Commissions on Dams; however, a tangible shift in national approaches has yet to be observed. The World Commission on Dams in 2000 noted that the appropriate consultative framework for such large dam projects was one already clearly set out by the United Nations Charter (1945) and International Declaration of Human Rights (1947) (World Commission on Dams, 2000). These rights include being consulted and the right not to have property arbitrarily taken. Later UN declarations, such as the Declaration on the Right to Development (1986) and the Rio Declaration on Environment and Development Principles (1992), have further strengthened the notion that any assessment of such projects incorporate a "rights and risk" approach where all stakeholders are involved (Tilt et al., 2009). Clearly the issue of sovereignty and rights is a much more complex one in the context of the Mekong Basin where more than one state share the resource. A 1970 study by the UN made the following observation which is as relevant today as when it was made:

Even in the best of circumstances joint use of international waters can give rise to ill feeling and political tension. Although there may be on all sides a sincere will to cooperate, questions of accuracy of flow measurements and of the justice of water allocations may lead to difficulties.... These factors, combined with the usual political differences arising in any international basin, tend to aggravate rather than ease the problem of integrated planning; in this respect it often differs from the planning involved in a national basin under the rule of a single Government. (Jacobs, 1995, p. 146)

Where policy alterations to improve the environmental and social outcomes of dams are failing, it is important that engineering designs for dams attempt to minimise the negative outcomes for communities and the environment. Nations need to recognise that the benefits to their neighbour are also benefits to themselves. After World War 2 the United States gave extensive aid to Europe for their own benefit, to ensure they had someone to trade with. A similar approach is surely required with the shared resource that the Mekong is. The nations of Southeast Asia need to develop this resource to achieve the greatest social, economic and environmental outcomes possible. 


\section{THE ROLE OF ENGINEERS IN ENSURING ENVIRONMENTAL AND SOCIAL JUSTICE}

The social, environmental and economic impacts of engineering projects such as damming in the Mekong Basin are not only local but also regional and global. Therefore, it is important that engineers consider the wider consequences of their decisions. Engineers have ethical as well as technical responsibilities when they undertake a project. This should encompass identifying all of the options available to resolve a problem, and clearly articulating the social, environmental and economic impacts. They possess the skills to assess the longer-term, farther-reaching impacts of dams, and adjust designs to minimise detrimental impacts. Currently many of these issues are not considered in the traditional environmental and social impact assessments of engineering dam projects, but they can easily be incorporated. Engineers also need to add effective praxis to these technical skills, be actively engaged in working with communities, and as experts advocate with other major non-local stakeholders for socially and environmentally just outcomes.

It is essential that future engineering work draws on the knowledge gained through postdevelopment assessment of dam impacts both nationally and internationally, in order to improve dam design, or recommend that dams not be constructed where the impacts will be harmful to society and the environment. Engineers have a role to explain to the decision makers the need to cover this broader scope. If, then, a decision is made that is not an appropriate one, they have an ethical responsibility to withhold participation in the project (Cambodia Engineers Without Borders Returned Volunteer, interviewed 10Nov2010; Cambodia Engineers Without Borders Community Partner, interviewed 2Nov2010).

\section{Engineers' Role to Inform Decision Making}

Large dam projects are generally completed to increase water security for a nation or for the production of hydroelectric power or both. Both of these goals have immediate benefits to the local community and nation, but generally result in other less positive consequences for affected communities. The human impacts and problems associated with large-scale dam projects around the world have already been well documented (Egre \& Senecal, 2003). There is a greater role that can be played by engineers to challenge and present solutions to problems determined to arise from specific projects. For example, some alternative options to large dams include small scale in situ hydropower systems, utilisation of other power production technologies and improving water consumption and treatment practices. These alternatives may well present a better outcome for local and downstream communities as well as better overall economic results for the country. When impacts are not properly addressed, the project is not accounting for the true cost and risks of substantial mitigation work, the lost revenues for impacted communities or the potential loss of reputation which impacts the license to operate large corporations. In the context of the Mekong, decision makers need to be aware of the options available so that they can make informed decisions for the future of the Mekong River region and, most importantly, impacted communities need to be involved in the decision-making processes in meaningful and not token ways (Cambodia Engineers Without Borders Volunteer, interviewed 5Nov2010; Vietnam Engineers Without Borders Volunteer, interviewed 4Nov2010; Cambodia Engineers Without Borders Returned Volunteer, interviewed 10Nov2010; Cambodia Engineers Without Borders Community Partner, interviewed 2Nov2010).

\section{Engineering's Role in Development}

Engineering is often touted as being an essential tool for development. Traditionally, development has been defined as increasing the economic wealth and technological means of a society. However, a more current definition is that development aims to assist people in addressing their basic human 
needs and improving their quality of life (United Nations Development Programme, 2010). Engineers possess skills which may positively impact society, increase sustainable development and reduce poverty. Engineers also possess skills which, in the name of traditional development, have led to the destruction of ecosystems and negative social impacts on communities. This is evident from the outcomes of many engineering projects, including current dam construction in the Mekong Basin.

Monetary concerns are often considered the most pressing consideration in terms of engineering projects, perhaps due to the hegemonic perception of 'The Economy' as primary in the national interest and wellbeing. In times of economic crises, environmental and social considerations are often overlooked, especially when these might be thought of as longer-term problems, not something of immediate concern. Traditional engineering projects have often failed to recognise their broader implications on human life and the environment as a whole. As Riley points out, engineers tend to see science as "objective" and technology as "neutral", and ignore the "social forces that demand certain forms of technology" (2008, p. 42). Instead of being neutral, every engineering project carries with it "a set of values and assumptions" which are often those of the most powerful stakeholders.

Environmental impact assessments focus heavily on the immediate, and often obvious, outcomes of engineering projects. These assessments may not consider the longer-term effects on the physical and human ecology of an area. This is a particularly difficult task in large projects, such as the damming of the Mekong River, where ecological and human impacts can be felt many thousands of kilometres downstream. Hence, the ecological predictions of scientific models and studies of hydropower dams must be considered by engineers early in the design stage as part of good praxis. This approach would allow scientific and technical predictions to be combined with political and social assessments to influence decisions over whether dams can be built with minimal environmental impact and in a way that protects the social and environmental rights of affected communities. To date, such concerns have had little consideration in the design and construction of dams along the Mekong (Keskinen \& Kummu, 2010).

Social impact assessments, where they are performed, generally consider only the immediate temporal and spatial impacts of projects. Governments compensate (albeit often inadequately) communities around dams (Tilt et al., 2009), where impacts such as displacement and loss of traditional livelihoods are clear and immediate. However, it is contentious as to whether monetary compensation replaces the loss of culture, income-generating activities and ecosystems associated with dam construction. Such compensation schemes do not tend to consider communities downstream of dams or future generations of families relocated by dam construction. It is essential that the impacts of dam construction on all communities influenced by dams are considered early in the decision-making process and that, wherever possible, engineers account for these shortcomings by altering dam designs and/or, acting in an ethically responsible manner, withdraw their services from such projects. Given how problematic these issues are within the context of a single state, the situation along the Mekong River is exponentially more problematic involving six sovereign states. Critically, engineers must also contribute to the debate surrounding whether hydropower dam projects are appropriate forms of development within particular contexts and regions. It is the engineers who have the technical ability to improve practices for better consideration of the environment and communities as well as to help determine where large-scale dam projects might not be the best solution.

Since hydropower dams have often been built in the past without sufficient consideration of environmental and social impacts, engineers from various non-governmental organisations (NGOs) 
often work with affected communities to restore the ecological and societal damage caused by large dam construction. Grassroots NGOs have a key role to play in the development of the Southeast Asia region, and the technical and managerial skills that engineers possess are a key need for these organisations. Currently, engineers often do not realise that they have the skills to assist these communities to improve their quality of life, due to a lack of exposure in their university education and through the workplace. One NGO, Engineers Without Borders Australia, works in partnership with developing communities both within Australia and overseas, assisting them to gain access to the knowledge, resources and appropriate technologies they need to improve their livelihoods. This organisation connects students and professionals to developing communities, enabling these engineers or aspiring engineers to provide technical, management and educational support either remotely from Australia or via a direct volunteer placement. Many projects, particularly in Cambodia, are based around water projects along the Mekong River and Tonle Sap, and are an excellent example of engineers utilising their technical skills for environmental and societal benefit. Although this work of engineers in assisting affected communities is crucial, it is questionable whether engineering decisions within the dam design and building process could have prevented these consequences from the outset.

There is significant development occurring along the Mekong River which is apparently providing a localised benefit to the communities involved, through job creation or more immediate access to resources. However, the longer-term consequences of these activities in many cases are unclear due to a lack of proper investigation and assessment of downstream impacts. The current development model in the Mekong Region is very focused on national economic aspects, as this is believed to flow through to the community through improved services and employment. The assumption that continuous (and often unregulated) growth is beneficial to communities needs to be challenged (Simms, Johnson, \& Chowla, 2010). Feedback received from those working with communities in Cambodia indicates that growth is causing the nation to move away from sustainable development, with sustainability indicators declining in all areas (Cambodia Engineers Without Borders Community Partner, interviewed 2Nov2010). If this is allowed to continue it will not only harm the environment, but also decrease the economic benefits from this process. One clear example is the decreasing size of fish and fish stocks in the Tonle Sap region. Osborne (2009, p. 11) notes that "in Cambodia, the country for which the most detailed information is available, fish catches per person have declined from a figure of $350 \mathrm{~kg}$ in 1940 to less than $200 \mathrm{~kg}$ in 2003". The decreasing fish stocks along the basin are attributed to overfishing and dams upstream. Whilst fishermen may still be able to harvest the same total volume of fish from the lake (with more fishermen operating), the smaller fish they catch are less valuable and a clear indication of long-term ecological change. This is directly impacting their livelihoods and causing an already marginalised group in society to be even more economically disenfranchised (Cambodia Engineers Without Borders Community Partner, interviewed 2Nov2010). The engineers who design dams must consider their impact on issues such as fish migration and biodiversity, and whether such consequences are truly justifiable for the benefit of economic growth. Also, emerging engineering techniques may be able to be incorporated into dams to address such issues of environmental importance, and these must be considered by design engineers. Such techniques have not been seen on any existing dams of the Mekong.

\section{THE FUTURE}

Clearly the issue of rights and of social justice in dealing with such projects raises questions for those who are involved in the planning and construction of large hydraulic schemes such as dams. Osborne notes that one of the reasons for the surge in dam proposals along the Mekong since 2004 is the fact that capital for such projects is now available from "commercial sources rather than from 
international organisations such as the World Bank and the Asian Development Bank" (Osborne, 2009 , p. 22). In the 1980s, organisations such as the World Bank and the Asian Development Bank began to subject loans for development projects to stricter compensation guidelines because of grave concerns about issues of rights and justice with regards to displaced communities. The shift in focus was towards taking greater consideration of social and environmental outcomes. This included "resettlement minimisation" and the focusing in assessment of projects on the link "between the civil engineering solutions adopted ... and the social engineering required for their adequate design and implementation" (Cernea, 1988, p. 5). The recent use of more commercial sources of funding begs the question of whether or not, and to what extent, commercial investments and firms/businesses (in the case of dam construction there are any number of international players) are bound by internationally agreed upon ideas about development linked to the rights of stakeholders. How far should interest groups go to ensure that more than just lip service is paid to rights and social justice for those affected by the projects they will initiate? This paper argues that the same question is an important one for individuals such as engineers who might be assigned to work on such ventures by their managers. This is particularly relevant in situations such as one finds along the Mekong, where issues of state corruption and authoritarianism make the entire issue of human rights (never mind environmental concerns) highly problematic. Further, even if a project has clear benefits for the host country, but possible negative impacts for several other riparian states and peoples, what responsibility does the corporation and individual have? Again this is particularly important given that the only bodies with any sort of oversight of development along the Mekong have insufficient power to enforce binding commitments related to hydropower and other development projects.

Engineers are taught technical skills within their degrees, often with little consideration of the global political and economic context within which their work exists. The potential for engineering projects to impact upon communities and the environment suggests that engineers must be educated early on about the impacts of their decisions, and the importance of praxis. As previously suggested, engineers have the technical skills to help ensure environmentally and socially just outcomes are achieved via the type and construction features of projects. However, they also need to be able to recognise the importance of the social, cultural and historical environments in which they work and which have shaped their own values and those of other project stakeholders.

Engineers clearly have a role to play in assisting to communicate the impacts that individual nations will have on other nations as a result of development activities. By taking a holistic view of the Mekong Basin and using techniques such as game theory coupled with more traditional approaches such as impact studies and social impact assessments it may be possible to reduce the negative outcomes on downstream nations and generate positive benefits for all involved. To achieve this, an accepted mechanism is required to enable compensation of other countries when activities such as dams and industrial work are undertaken. This compensation would be based on the impacts of the development on other countries and would take the form of either direct compensation or, ideally, the development of infrastructure to prevent or mitigate impacts. Once nations are committed to compensate each other they will be forced to take a more holistic view. Such an approach must ultimately also include decision-making involvement by communities most affected by hydraulic projects.

The challenges that have been observed in past development along the Mekong River demonstrate an opportunity for engineers to play a role in improving regional development outcomes. It has been identified that the utilisation of small-scale, holistic approaches to working with developing communities has enabled them to access their self-identified needs and improve their quality of life (Cambodia Engineers Without Borders Returned Volunteer, interviewed 10Nov2010). These 
grassroots efforts are proving helpful in offsetting the consequences of both human errors with respect to development projects in the Mekong Basin as well as changes being brought about by climate change. They are also clear evidence of the need for good praxis by engineers. These efforts, this paper suggests, need to be taken further, and the technical skills and knowhow of engineers needs to be employed from the outset of projects to ensure the best possible technical solutions to projects are fully understood and acted upon within a framework of meaningful engagement with local communities. It is particularly important in the interests of social justice to ensure that the least politically empowered members of communities have access to such knowledge to inform their own decision making (again the importance of good praxis is evident) during the early stages of project planning. There are ample examples of external organisations implementing projects that do not benefit the broader community, but which proceed to advance private interests (Cambodia Engineers Without Borders Community Partner, interviewed 2Nov2010). This demonstrates a need for engineers to broaden their understanding of their roles in projects like dams to incorporate social, environmental and economic factors, and clearly articulate these aspects for each engineering option available (Cambodia Engineers Without Borders Community Partner, interviewed 2Nov2010). As noted already, engineers are not neutral bystanders in these processes, though this is often how they see themselves. Rather, they are political actors whose decisions and actions can well determine the extent to which outcomes are likely to be socially and environmentally just. This paper argues that they have an ethical obligation to be active in praxis and to opt out of projects they deem sufficiently problematic in terms of achieving just outcomes.

\section{ACKNOWLEDGEMENTS}

This article was made possible by support from the Australian Learning and Teaching Council Grant, "Engineering Education for Social and Environmental Justice" (CG10-1519). We are grateful to the interviewees for sharing their experiences with us. We would also like to acknowledge the work of IJESJP reviewers and editors in assisting us to improve the manuscript.

\section{INTERVIEWEES}

Cambodia Engineers Without Borders volunteer. Interviewed by Daniel I. Loden. 5 November 2010. Vietnam Engineers Without Borders volunteer. Interviewed by Daniel I. Loden. 4 November 2010.

Cambodia Engineers Without Borders returned volunteer. Interviewed by Daniel I. Loden. 10 November 2010.

Cambodia Engineers Without Borders Community Partner. Interviewed by Daniel I. Loden. 2 November 2010.

\section{REFERENCES}

Adeola, F. O. (2000). Cross-national environmental injustice and human rights issues: A review of evidence in the developing world. The American Behavioral Scientist, 43(4), 686-706.

Asian Development Bank. (2011). Greater Mekong Sub-Region. Retrieved 13th September, 2011, from http://www.adb.org/gms

Australian Government. (2011). National Greenhouse Gas Inventory, Accounting for the Kyoto Target, December Quarter 2010. Barton, ACT: Australian Government.

Baird, I. G., \& Beasley, I. L. (2005). Irrawaddy dolphin Orcaella brevirostris in the Cambodian Mekong River: an initial survey. Oryx, 39(3), 301-310. doi: 10.1017/s003060530500089x

Bakker, K. (1999). The politics of hydropower: developing the Mekong. Political Geography, 18(2), 209-232.

Bangkok Post. (2011a, 13/03/11). Xayaburi dam proposal was "poorly researched", Bangkok Post. Retrieved from $\quad$ http://www.bangkokpost.com/news/local/231358/xayaburi-dam-proposal-was-poorly-

researched 
Bangkok Post. (2011b, 13/03/11). Xayaburi dam work begins on sly, Bangkok Post. Retrieved from http://www.bangkokpost.com/news/local/232239/xayaburi-dam-work-begins-on-sly

Benger, S. N. (2007). Remote sensing of ecological responses to changes in the hydrological cycles of the Tonle Sap, Cambodia Igarss: 2007 IEEE International Geoscience and Remote Sensing Symposium, Vols 1-12 Sensing and Understanding Our Planet (pp. 5028-5031). New York: IEEE.

Cernea, M. M. (1988). Involuntary resettlement in development projects: policy guidelines in World Bankfinanced projects (World Bank Technical Paper). Washington D.C.: World Bank.

Chinese National Committee on Large Dams. (2011). Chinese National Committee on Large Dams. Retrieved 13th September, 2011, from http://www.chincold.org.cn/english.asp

Coutant, C. C., \& Whitney, R. R. (2000). Fish behavior in relation to passage through hydropower turbines: A review. Transactions of the American Fisheries Society, 129(2), 351-380.

Donnelly, J. (2006). International Human Rights. Westview Press.

Dugan, P. J., Barlow, C., Agostinho, A. A., Baran, E., Cada, G. F., Chen, D. Q., . . W Winemiller, K. O. (2010). Fish migration, dams, and loss of ecosystem services in the Mekong Basin. Ambio, 39(4), 344-348.

Economy, E. C. (2005). The River Runs Black: The Environmental Challenge to China's Future. Ithaca and London: Cornell University Press.

Egre, D., \& Senecal, P. (2003). Social impact assessment of large dams throughout the world: lessons learned over two decades. Impact Assessment and Project Appraisal, 21(3), 215-224.

Fu, K. D., \& He, D. M. (2007). Analysis and prediction of sediment trapping efficiencies of the reservoirs in the mainstream of the Lancang River. Chinese Science Bulletin, 52, 134-140. doi: 10.1007/s11434-007-70260

Fu, K. D., He, D. M., \& Lu, X. X. (2008). Sedimentation in the Manwan reservoir in the Upper Mekong and its downstream impacts. Quaternary International, 186, 91-99. doi: 10.1016/j.quaint.2007.09.041

Hall, K. R. (1992). Economic History of Early Southeast Asia. In N. Tarling (Ed.), The Cambridge History of Southeast Asia (Vol. 1, pp. 195-196). Singapore: Cambridge University Press.

Hirsch, P. (1998). Dams, resources and the politics of environment in mainland Southeast Asia. In P. Hirsch \& C. Warren (Eds.), The politics of environment in Southeast Asia: resources and resistance. London: Routledge.

Jacobs, J. W. (1995). Mekong Committee history and lessons for river basin development. The Geographical Journal, 161(2), 146-147.

Jacobs, J. W. (2002). The Mekong River Commission: transboundary water resources planning and regional security. Geographical Journal, 168, 354-364.

Kang, B., He, D. M., Perrett, L., Wang, H. Y., Hu, W. X., Deng, W. D., \& Wu, Y. F. (2009). Fish and fisheries in the Upper Mekong: current assessment of the fish community, threats and conservation. Reviews in Fish Biology and Fisheries, 19(4), 465-480. doi: 10.1007/s11160-009-9114-5

Keay, J. (2005). Mad about the Mekong: exploration and empire in South East Asia. London: Harper Collins Publishers.

Keskinen, M., \& Kummu, M. (2010). Impact Assessment in the Mekong: Review of Strategic Environmental Assessment (SEA) \& Cumulative Impact Assessment. Helsinki, Finald: Water \& Development Publications.

Kummu, M., \& Varis, O. (2007). Sediment-related impacts due to upstream reservoir trapping, the Lower Mekong River. Geomorphology, 85(3-4), 275-293. doi: 10.1016/j.geomorph.2006.03.024

Lamberts, D. (2006). The Tonle Sap Lake as a productive ecosystem. International Journal of Water Resources Development, 22(3), 481-495. doi: 10.1080/07900620500482592

Live \& Learn Environmental Education. (2007). Tonle Sap Information Guide. Phnom Penh, Cambodia: Live \& Learn Environmental Education.

Lu, X. X., \& Siew, R. Y. (2006). Water discharge and sediment flux changes over the past decades in the Lower Mekong River: possible impacts of the Chinese dams. Hydrology and Earth System Sciences, 10, 181-195.

McLaren, A. (2011). Environment and cultural heritage in China: Introduction. Asian Studies Review, 35(4), 429-437.

Mekong River Commission. (2010). About the MRC. Retrieved 23th May, 2012, from http://www.mrcmekong.org/

Mitchell, M. (1998). The political economy of Mekong Basin development. In P. Hirsch \& C. Warren (Eds.), The politics of environment in Southeast Asia: resources and resistance. London: Routledge.

Molle, F., Foran, T., \& Kakonen, M. (Eds.). (2010). Contested Waterscapes in the Mekong Region Hydropower, Livelihoods and Governance. Singapore: Institute of Southeast Asian Studies. 
Ngamsiri, T., Nakajima, M., Sukmanomon, S., Sukumasavin, N., Kamonrat, W., Na-Nakorn, U., \& Taniguchi, N. (2007). Genetic diversity of wild Mekong giant catfish Pangasianodon gigas collected from Thailand and Cambodia. Fisheries Science, 73(4), 792-799. doi: 10.1111/j.1444-2906.2007.01398.x

Nussbaum, M. (2003). Capabilities as fundamental entitlements: Sen and social justice. Feminist Economics, 9(2/3), 33-59.

Osborne, M. E. (2000a). The Mekong: turbulent past, uncertain future. St Leonards, N.S.W.: Allen and Unwin.

Osborne, M. E. (2000b). The strategic significance of the Mekong. Contemporary Southeast Asia, 22(3), 429444.

Osborne, M. E. (2009). The Mekong River under threat. Lowy Institute for International Policy, Sydney: Longueville Press.

Osborne, M. E. (2011, 29/06/11). Mekong dam plans threatening the natural order, The Australian. Retrieved 24th February 2012 from http://www.theaustralian.com.au/news/world/mekong-dam-plansthreatening-the-natural-order/story-e6frg6ux-1226083709322

Rawls, J., \& and Kelly, E. (2001). Justice as fairness: a restatement. Cambridge, U.S.: Harvard University Press.

Riley, D. (2008). Engineering and Social Justice. San Rafael, U.S.: Morgan \& Claypool.

Schilt, C. R. (2007). Developing fish passage and protection at hydropower dams. Applied Animal Behaviour Science, 104(3-4), 295-325. doi:

10.1016/j.applanim.2006.09.004

Scudder, T. (2005). The Future of Large Dams: Dealing with Social, Environmental, Institutional and Political Costs. London: Earthscan.

Shaffer, L. N. (1996). Maritime Southeast Asia to 1500. Armonk, NY: M. E. Sharpe.

Shiva, V. (2002). Water Wars: Privatization, Pollution and Profit. Cambridge, MA: South End Press.

Simms, A., Johnson, V., \& Chowla, P. (2010). Growth isn't possible: Why we need a new economic direction. London: New Economics Foundation.

Smil, V. (2004). China's past, China's future: energy, food, environment. New York: Routledge.

Snowy Hydro Limited. (2011). Snowy Mountains Scheme. Retrieved 13th September, 2011, from http://www.snowyhydro.com.au/LevelThree.asp?pageID=244\&parentID=66\&grandParentID=4

Tilt, B., Braun, Y., \& He, D. M. (2009). Social impacts of large dam projects: A comparison of international case studies and implications for best practice. Journal of Environmental Management, 90, S249-S257. doi: 10.1016/j.jenvman.2008.07.030

United Nations. (1948). Universal Declaration of Human Rights. Geneva: United Nations.

United Nations Department of Peacekeeping Operations Cartographic Section (Cartographer). (2004). Greater Mekong Subregion. Retrieved from http://www.un.org/depts/Cartographic/map/profile/mekong.pdf

United Nations Development Programme. (2010). Human Development Report 2010. New York: Palgrave Macmillan.

Vickery, M. (1998). Society, economics, and politics in pre-Angkor Cambodia: the 7th-8th centuries. Tokyo: Centre for East Asian Cultural studies for UNESCO.

Vietnam Business and Economy News. (2011, 23/02/11). Experts worry about Mekong River power plant, Vietnam Business and Economy News. Retrieved from http://www.vneconomynews.com/2011/02/experts-worry-about-mekong-river-power.html

Wolf, A. T. (2003). "Water Wars" and other tales of hydromythology. In B. McDonald \& J. Douglas (Eds.), Whose Water is it?: The Unquenchable Thirst of a Water-Hungry World (pp. 109-124). Washington, D.C.: National Geographic Society.

World Commission on Dams. (2000). Dams and Development: a New Framework for Decision-making. London: Earthscan.

Zhai, H. J., Cui, B. S., Hu, B., \& Zhang, K. J. Prediction of river ecological integrity after cascade hydropower dam construction on the mainstream of rivers in Longitudinal Range-Gorge Region (LRGR), China. Ecological Engineering, 36(4), 361-372. doi: 10.1016/j.ecoleng.2009.10.002 